\title{
Ler, no corpo da "mestiça", beleza, corporalidades e fronteiras no parentesco nikkey. as experiências de mulheres nipodescendentes no Brasil ${ }^{*}$
}

\author{
Érica Rosa Hatugai**
}

\begin{abstract}
Resumo
Por meio de uma pesquisa etnográfica, feita na cidade de Marilia-SP, com famílias de nipodescendentes compostas em diferentes momentos históricos, este artigo analisa parentesco, gênero, pertencimentos, corporalidades, beleza e tensões que atravessam as relações nipônicas no Brasil. O olhar se volta, especialmente, para trajetórias femininas, uma vez que os jogos e as tensões no parentesco recaem intensamente sobre os corpos das mulheres, fortemente, os das "mestiças".
\end{abstract}

Palavras-chave: Migrações, Família, Nipodescendentes, Corporalidades, Parentesco.

\footnotetext{
* Recebido em 15 de novembro de 2020, aceito em 25 de outubro de 2021. Agradeço a Igor Machado pela orientação e apoio às minhas pesquisas, aos meus companheiros pesquisadores do LEM pelas trocas de saberes, às companheiras organizadoras deste dossie pelas trocas de saberes e solidariedade, e profundamente à cadernos pagu pela oportunidade de compartilhar esta pesquisa. Dedico este texto ao meu tio avô Taro Masuda (1922-2019), o imigrante de nossa família.

** Pesquisadora do Laboratório de Estudos Migratórios -LEM, Universidade Federal de São Carlos (UFSCar), São Carlos, SP, Brasil. ehatugai@gmail.com / https://orcid.org/0000-0003-2380-4653
} 
Reading Beauty, Embodiment and Frontiers of Nikkei Kinship in the "Mestizo" Body: Experiences of Women Japanese Descendants in Brazil

\begin{abstract}
This paper presents issues related to kinship, gender roles, belonging, embodiments, beauty and tensions in the Japanese universe of Brazil, based on ethnographic research carried out with several multigenerational families, some of which are composed of Japanese descendants and others by Japanese descendants mixed with non-Japanese descendants, all of them living in the city of Marilia, in the state of São Paulo, Brazil. It focuses on the female perspective and trajectories, since the opposition and tension surrounding kinship are more reflected more intensely on female bodies, especially those of "mestizo" women.
\end{abstract}

Keywords: Migration, Family, Japanese descendants, Embodiment, Kinship. 


\section{Introdução}

Por meio de uma leitura antropológica, o intuito deste estudo foi compreender as silenciosas tensões no parentesco "japonês" ${ }^{1}$ no Brasil percorrendo sobretudo as corporalidades dos sujeitos, em especial os corpos femininos nikkey ${ }^{2}$. Tal centralidade dos corpos femininos ocorre pois as mulheres nipodescendentes e os seus corpos foram recorrentemente representados como territórios de tensões e intersecções a produzir diferenciações no parentesco quando pensado sob a luz das famílias "japonesas" (formadas somente por nipônicos não miscigenados) e das famílias "mistas'3 (formadas por nipodescendentes com não nipodescendentes) no Brasil. No interior desses arranjos, questões como continuidade familiar, comportamentos, beleza e sexualidade impactavam sobremaneira as imagens produzidas sobre os corpos femininos nipodescendentes. E apesar de pairar sobre as mulheres japonesas e nipodescendentes a estereotipia de apagadas, silenciosas $e$ submissas (Sakurai, 2008), por meio de seus afetos elas conseguiam romper com tais estereótipos. Nesses processos desiguais, escolhas afetivas eram agenciadas e corporalidades ressignificadas, tal como mostram as análises das concepções de gênero e beleza entre os nikkey e a sociedade majoritária. Com base na análise antropológica mediada por uma perspectiva dos estudos de gênero acerca dos intercruzamentos e intersecções de categorias, práticas sociais, jogos sérios e agências dos sujeitos (Brah, 2006; Ortner, 2007; Piscitelli, 2008), o desejo aqui manifesto é apreender questões múltiplas produzidas em um contexto migratório específico: a imigração e a presença japonesa no Brasil, mais precisamente na cidade e região de Marília, Centro-Oeste Paulista, conhecida por abrigar o maior número de imigrantes japoneses e seus descendentes no interior de São Paulo4.

Por meio de uma pesquisa etnográfica realizada com imigrantes japoneses e nipodescendentes de diferentes gerações na região Centro-Oeste Paulista, em diversos contextos como a Associação Cultural e Esportiva Nikkey de Marília, espaços religiosos protestante e budistas e no comércio local, este texto se atém a questões múltiplas de um parentesco específico: o "japonês" no Brasil, bem como suas continuidades, derivações e tensões, e o modo como ele intersecciona noções de corporalidade, raça, gênero, beleza, racismo, estrangeirização, exotização e agências. Tal investigação proporciona novas compreensões para o campo dos estudos sobre

\footnotetext{
1 "Japonês", entre aspas, é categoria nativa brasileira para referir-se a imigrantes japoneses e demais asiáticos e seus descendentes. Quando tal categoria é utilizada entre nipodescendentes, ela não está a comunicar nacionalidade ou tampouco crise de identidade entre ser brasileiro ou japonês, mas, sim, a experiência de ser brasileiro descendente de japoneses em uma sociedade que constantemente estrangeiriza essas pessoas por sua corporalidade, sobretudo pelas marcas corporais dos olhos "puxados" (asiáticos). A categoria nativa "japonês" está autorizada quando entre nipônicos e seus descendentes, pois, lhes sendo familiar, figura como código de grupo, bem como pode possuir tom jocoso autorreferencial. Ao mesmo tempo, quando tal categoria é utilizada por não nipodescendentes no Brasil, os nipônicos relatam se tratar de situações racistas e ofensivas. Nesse caso, a categoria "japonês" possuiria tom xenofóbico, ofensivo e pejorativo (Hatugai, 2011).

2 Nikkey ou nikkeyjin são terminologias da língua japonesa para referir-se aos imigrantes japoneses e seus descendentes que vivem fora do Japão. Nesta pesquisa, nikkey e/ou nikkeyjin são usadas tanto como terminologias da língua japonesa quanto como categorias nativas para meus interlocutores. Na língua japonesa, não há plural para essas terminologias, e, ao longo do texto, as terminologias em japonês serão apresentadas em itálico e no singular, seguindo os modelos citados acima. Ainda, as categorias nativas utilizadas pelos interlocutores estarão grafadas entre aspas.

3 A categoria família "mista" surgiu como proposição para designar o arranjo de famílias formadas por nipodescendentes com não nipodescendentes, pois, no momento da pesquisa, entre 2014 e 2015, não havia uma categoria nativa socialmente cristalizada para tal arranjo. As famílias de "japoneses" e as famílias de nikkey com não nikkey classificavam tal arranjo como "famílias misturadas". Ambas salientavam não haver mais diferenças entre esses dois modelos, pois, na atualidade, não haveria mais distinções entre elas. Entretanto, na ocorrência de explicações sobre os modos de cada arranjo, as menções a famílias "japonesas" e "misturadas" prevaleciam, denotando uma diferenciação no parentesco. A fim de transmitir ao máximo os sentidos das falas dos sujeitos, adotei a categoria 'mista' (entre apostrofes) para demarcar o tipo exclusivo de arranjo familiar pertencente e negligenciado na história migratória e presença nipônica no Brasil.

4 Nos anos de 2014 e 2015, data de minha pesquisa de campo, a Associação Cultural Nikkey de Marilia estimou a população nikkey local em 2.000 famílias, algo em torno de 10.000 nikkey. Nas mesmas datas, os dados do IBGE estimavam a população "amarela" (termo genérico para asiáticos) local em 5.808 (2,68\%). Porém, esse número pode não ser exato, já que o censo no Brasil é auto classificatório e a sociedade brasileira utiliza o registro marca corporal "cor da pele" com muita plasticidade. Isso significa que muitos descendentes de japoneses podem autodeclarar cores de pele que não a amarela. Para mais, ver Hatugai (2018).
} 
migrações, pois considera o deslocamento migratório ao longo do movimento de diferentes gerações de nipodescendentes e suas concepções nativas sobre parentesco, corporalidades e os papeis de gênero no interior dessas famílias. Para compreender tais questões, faz-se necessário uma breve abordagem da imigração japonesa pelo recorte do parentesco, a fim de compreender suas filiações históricas na atualidade ${ }^{5}$.

\section{Breves considerações sobre a imigração japonesa no Brasil}

O Brasil concentra a maior população de imigrantes japoneses e nipodescendentes no mundo: um milhão e meio de pessoas ${ }^{6}$. Essa interconexão entre Brasil e Japão teve início em 18 de junho de 1908 quando aportaram em Santos os primeiros 781 imigrantes. Desde o início da imigração japonesa, a instituição da família se fez importante, pois em 1906, Jorge Tibiriçá, então presidente do estado de São Paulo, regulamentou a Lei n 1045C, de 27 de dezembro de 1906, que somente permitia a vinda, para o território brasileiro, de famílias imigrantes japonesas compostas por, no mínimo, três indivíduos "aptos"7 para o trabalho na lavoura (Harada, 2009). Desde o início da imigração, a hostilidade dos receptores aos costumes imigrantes como a religiosidade, a alimentação, a dinâmica familiar e, notadamente, a língua constituíram uma das principais dificuldades de integração dos imigrantes japoneses à nova sociedade. $\mathrm{O}$ fechamento nas colônias, o isolamento geográfico, cultural e linguístico gerou confrontos com o ideário de nação brasileira do início do século XX, e os brasileiros interpretaram tal fechamento como recusa e invasão à nação brasileira. A vinda dessa mão de obra não europeia gerou caloroso debate político, científico e intelectual na época, pois a ala favorável à imigração via no estereótipo nipônico de "trabalhador dócil, servil e silencioso" valores a serem incorporados à sociedade brasileira, ao passo que a ala contrária via na "feiura e reserva japonesa" o risco de enquistamento racial, a "mongolização" e o medo do "amarelamento" da nação (Lesser, 2001). Porém, até o final da Segunda Grande Guerra, o sonho de retorno à terra natal foi constante na vida dos imigrantes. Para tanto, eles deveriam reservar o máximo do ethos japonês para quando do retorno, pois a perda dos modos japoneses implicaria sua marginalização social na sociedade de origem. Assim, o fechamento dos imigrantes em suas famílias e grupo étnico foi um caminho para se manterem japoneses ou manterem a sua japonesidade (Hatugai, 2011, 2013; Machado, 2011).

O núcleo familiar como unidade de produção e centro de perpetuação do parentesco era primordial para essas famílias. De acordo com Cardoso (1998) e Sakurai (1993), o parentesco aportado pelos imigrantes era constituído pela concepção de família tradicional japonesa, segundo a lógica do ie, uma instituição fundada num sistema hierárquico organizado com base no princípio da descendência patrilinear estruturado na devoção filial, na residência comum, na divisão de papeis de gênero e geracional, na unidade de produção e no culto aos antepassados, sendo todos esses elementos entrelaçados para o bem estar coletivo. Nesse sistema, o chonan (filho primogênito) possuía o direito à herança $e$ sucessão $e$ o dever de manutenção, sustento $e$ proteção do núcleo familiar, perpetuando o nome da família e sua ocupação.

É possivel compreender como a instituição do ie se perpetuava no tempo e no espaço com base na transmissão patrilinear de pai para filho biológico ou adotivo, por meio da perpetuação do nome da família, também compreendido como honra (Sakurai, 1993; Sasaki, 2008; Silva, 2012). Segundo Cardoso (1998), é certo que, ao vermos esse modelo de família e o contexto da imigração, não estamos a discutir a continuidade desse parentesco sob um ponto de vista da inassimilação ou da aculturação dos imigrantes. O que trazemos à tona, nesse contexto, são as

\footnotetext{
5 Há vários autores consagrados para conhecer em detalhes a história da imigração japonesa no Brasil como Handa (1973), Lesser (2001), Saito (1973), Sakurai (1993, 2008), Schpun (2008) Vieira (1973), entre outros.

6 Dados da "Pesquisa de Opinião - Jovens Nikkey" realizada pelo Consulado Geral do Japão de São Paulo em 2013.

7 De acordo com Harada (2000), Vieira (1973), a exigência era de migrarem organizados em famílias compostas por, no mínimo, três indivíduos aptos para o trabalho com idades entre doze e quarenta e cinco anos. Os imigrantes maiores de sessenta anos eram considerados "inaptos ao trabalho", mas poderiam migrar desde que acompanhados de um individuo dito válido. De acordo com Handa (1973), tal exigência também impulsionou a formação de famílias "arranjadas": forjadas por pessoas sem laços de parentesco.
} 
mudanças socioculturais impostas pela nova realidade e o desejo de continuidade dos traços culturais, suas mudanças, transformações e conflitos ao longo das gerações.

A partir dessa concepção de família pode ser compreendido como a vida e os casamentos endogâmicos foram moldados pela geração imigrante no Brasil. Nesse sistema patrilinear, os modos de viver e os projetos da família eram todos traçados pelo chefe: um mundo projetado por homens e transmitido para os homens. Se explorado o mundo íntimo da casa, entretanto, via-se que tal arranjo patrilinear não significava que a mulher não possuísse papel primordial. Ao contrário, os estudos feministas de Yanagizako (1985) e as pesquisas de Sakurai (1993) ressaltaram a importância da mulher nessa família, pois todo o cuidado da casa, a participação no trabalho da lavoura e, sobretudo, a investidura para a produção de pessoas era tecida pelas mulheres por meio dos cuidados, alimentação, língua, costumes e educação nos moldes japoneses. Então, vir a ser japonês seria resultado e sucesso do papel feminino, porém o local primordial da mulher ficava ocultado pela representação do sistema patrilinear. Ao chefe cabia o trabalho para o sustento material do núcleo familiar, bem como traçar os projetos familiares do gambarê,, o "vencer na vida", por meio do trabalho e os estudos dos filhos, mas era sobre a mulher esposa que pairava toda a base para a concretização desses planos ${ }^{9}$.

O empenho da mãe japonesa em produzir e educar os filhos dentro dos padrões tradicionais morais e estéticos japoneses significava o cumprimento do dever da família e do exito de seu papel no seio familiar. Ou seja, as estereotipias que pairavam, $e$ ainda pairam, sobre a mulher japonesa $e$ a mulher nikkey como "apagadas e submissas" em nada correspondiam com a realidade de suas vidas. Isso posto, ao apreender a lógica do ie e as divisões de papeis de gênero e geracionais no seio da família imigrante e ao entender que tal lógica possui filiações na vida das famílias nipodescendentes, é possivel compreender a tônica da permanência dessa japonesidade. E nesse sentido, deve ser notado que para as duas primeiras gerações de famílias imigrantes nipônicas, a continuidade dos modos tradicionais japoneses foi possivel por meio da doação coletiva de seus membros na reprodução da própria ordem familiar. E, apesar de tratar-se de um sistema patrilinear calcado no nome e em hierarquias, era a mulher que movimentava o mundo para a perpetuação do parentesco.

\section{Tensionando (des)encontros por meio do discurso racial}

Com final da Segunda Guerra, a devastação do Japão e a pobreza dos imigrantes no Brasil, o sonho de retorno à terra natal foi definitivamente encerrado, mas os desencontros com a sociedade majoritária, não. A hostilidade dos brasileiros para com os japoneses era contínua, o fechamento dos nipônicos em suas "colônias"10 era interpretado como "enxofre" ao sonho de caldeamento da nação. Por outro lado, os imigrantes japoneses também tinham preconceito para com os brasileiros e os viam como gaijin ${ }^{11}$, "pessoas não confiáveis" preferindo viver entre os seus. Ambos os lados reservavam preconceitos e hostilidades para com o outro e isso era um jogo, uma via de mão dupla que se autoalimentava (Hatugai, 2018). Com a certeza de que todos teriam que se estabelecer no Brasil, a partir dos anos 60 as famílias formadas pelas gerações issei ${ }^{12}$ e nissei iniciaram um processo de ascensão econômica e social com o projeto de enviar, ao menos, um dos filhos para os bancos das universidades ${ }^{13}$. Eu acompanhei situações na região de Marília e Araraquara de filhas issei e nissei que não ingressaram nas universidades, mas empreenderam como autônomas se tornando

\footnotetext{
8 Ethos de dedicação, disciplina e esforços individuais e coletivos.

9 Para mais, ver o debate de Ribeira (2011) sobre a sexualidade de nipodescendentes gays e o papel da mãe no seio familiar.

${ }^{10}$ As chamadas associações culturais nipo-brasileiras. Para mais, ver Hatugai $(2011,2013,2018)$.

${ }^{11}$ Estrangeiro, aquele que está fora.

${ }^{12}$ Terminologia da língua japonesa para designar as gerações nikkey. A saber, issei: japonês imigrante, a primeira geração. Nissei: filho de imigrantes, a segunda geração. Sansei: neto de imigrantes, a terceira geração. Yonsei: bisneto de imigrantes, a quarta geração. Gossei: tataraneto de imigrantes, a quinta geração. Rokussei: tetraneto de imigrantes, a sexta geração e etc.

${ }^{13}$ Para mais, ver Schpun (2008).
} 
cabeleireiras, costureiras, proprietárias de comércio de alimentação ou administrando o comércio familiar, dentre outras atividades similares. Para os filhos que não ingressassem no ensino superior, a família buscava alternativas de possibilidades profissionais não subalternas. Mesmo tendo em vista tal movimento de ascensão social e integração econômica do grupo, contudo, isso não significaria a integração deles no imaginário de sociedade brasileira.

Os nikkey desafiaram, e ainda desafiam, uma dita concepção de brasilidade por meio de seus corpos, pois o mito da democracia racial reinante visualiza e constrói nas marcas simbólicas do corpo nikkey resistências ao caldeamento patriótico. Se entendermos que tal desejo implica o clareamento da nação e o apagamento de nossas múltiplas raízes culturais historicamente marginalizadas e estigmatizadas, notadamente, as populações indígenas e negras, o "valor" das marcas simbólicas corporais, também análogo à "raça", é um dos imperativos para a compreensão da sociedade brasileira. Na esteira de Guimarães (1999), a categoria raça em nossa sociedade possui plasticidade própria e pode ser compreendida como categoria do pensamento social, como categoria nativa brasileira biologizante e como categoria sociológica analítica para se pensar o racismo no Brasil. Tais classificações não necessitam ser compreendidas como categorias sobrepostas umas às outras, mas como adensamentos a serem apreendidos nas camadas dos discursos dos interlocutores. Majoritariamente, os nipodescendentes no Brasil já se depararam com camadas ambíguas de discursos raciais, a exemplo de "elogios" indicando nacionalidade ou etnicidade, como o "o teu povo é honesto e modelo" 14 , e ofensas e xenofobia, como "volta para tua terra!" ou a categoria "japonês" como xingamento. Tais camadas, além da violência, trazem à tona a persistência de marcar com exterioridade essa população no imaginário de nação no Brasil. A persistência em se estrangeirizar e exotizar o brasileiro nipodescendente como não brasileiro estaria manifestada na construção de suas marcas corporais simbólicas, nesse caso, a marca dos olhos: os "olhos puxados ou rasgados" seriam o símbolo eleito para a imposição de sua exterioridade e de outros asiáticos e seus descendentes, todos homogeneizados como "japoneses" ou "china" no vocabulário sócio cordial (Hatugai, 2018).

\section{Gênero e rupturas desiguais}

Apesar de os "japoneses" serem concebidos monoliticamente como todos "iguais"15, os sujeitos nipodescendentes confrontam essa estereotipia na medida em que se multiplicam diferenciações no interior da imigração e nas rupturas com os casamentos mistos. Os casamentos das primeiras gerações, sobretudo a issei, seguiram o princípio do miai: casamentos arranjados entre as famílias dos noivos. A concepção de amor romântico não era parte do parentesco japonês. Realizar o miai era símbolo da continuidade do tronco familiar mesmo no Brasil. Na geração nissei, alguns nipodescendentes iniciaram um movimento lento de casamentos fora da "colônia" com brasileiros não nipônicos. Nesse momento, romper com o miai significava desatar a ordem familiar, e como consequência ocorriam casos de deserdação, rupturas das relações familiares ou o suicídio dos filhos para não romperem as hierarquias de seu núcleo (Hatugai, 2018). Na geração sansei, os casamentos entre "japoneses" e "brasileiros" se tornam mais correntes, e esse tipo de união afetiva implicou novos arranjos no parentesco, com derivações de descendência onde antes imperava o desejo de continuidade ininterrupta do nome da família. Contudo, tal processo de abertura

\footnotetext{
${ }^{14}$ Sobre o imaginário e construção social de minoria “modelo", ver Dezem (2005), Kebbe e Machado (2013).

${ }^{15}$ Apesar do desconhecimento da sociedade majoritária, no interior da imigração japonesa há uma grande divisão e relações assimétricas de poder entre os japoneses do território e os okinawanos da ilha de Okinawa. Okinawa foi colonizada pelo império japonês em 1879, e a imposição da língua e educação de orientação japonesa sobre a cultura uchinaa foram meios de uniformização e tentativa de apagar a história de Okinawa. No interior da imigração japonesa, os okinawanos e seus descendentes relataram sempre ter sofrido discriminações por parte dos naichi (japoneses). Para mais, ver Kubota (2013), Yamashiro (2001). Ademais, em Elias e Scotson (2000), vemos a estigmatização da região da ilha norte de Hokkaido no Japão com os povos originários indígenas Ainu representados pela sociedade majoritária como grupo pária. Tal racismo também se estenderia para a população nipodescendente de Hokkaido, no Brasil: como alguns informantes me explicaram, há preconceito entre nipodescendentes porque a população de Hokkaido é vista como "povos da floresta" no Japão.
} 
desfrutado livremente pela geração sansei foi uma conquista advinda de lutas, sofrimentos $e$ rupturas sofridas pelas gerações anteriores.

Para esse artigo, não foi possível dispor de dados estatísticos sobre o gênero de maior prevalência de nipodescendentes das primeiras gerações casados com "brasileiros" ${ }^{16}$. As histórias de vida que acompanhei mostraram que, apesar de mais homens terem se casado com brasileiras, os homens e mulheres que rompiam com a ordem familiar fazendo valer seu afeto e escolha individual sofriam a quebra dos laços familiares. No entanto, às mulheres da primeira geração as privações foram mais implacáveis, vide o rompimento familiar, o julgamento social $e$ as desigualdades de gênero no ingresso ao mercado de trabalho. Apesar de as duas primeiras histórias que apresentarei terem se passado na minha região de origem, o noroeste paulista, elas se conectam com as histórias de diferentes regiões do interior paulista, denotando que, apesar do rompimento familiar valer para filhos e filhas, as mulheres enfrentariam maiores privações.

Em Olímpia, minha cidade natal, conheci Iolanda ${ }^{17}{ }^{18}$, uma comerciante issei que preferiu permanecer solteira por sua família não aceitar o casamento com brasileiros e duas issei que se casaram com "brasileiros": Yroko ${ }^{19}$ e Suzana ${ }^{20}$. Iolanda, por possuir independência financeira, recusou o miai, relatou à minha mãe que seu sonho era se casar com brasileiro, mas sua família jamais aceitou. E, após uma tentativa de namoro com um issei, ela preferiu permanecer solteira a ter que se casar contra sua vontade. Já Yroko, advinda de família rica proprietária de terras no interior paulista, relatou que se apaixonou por um brasileiro. Diante da recusa de sua família, ela teria seguido os seus sentimentos e se casado aos 20 anos com o esposo em 1965. Ele era brasileiro, pobre e trabalhador e ela foi deserdada. Seu esposo, apesar da profissão de motorista, tinha renda familiar modesta, e Yroko não pôde contar com o apoio de sua família na ocasião da chegada de seus dois filhos. Suas irmãs e irmãos formados em medicina a ajudavam financeiramente e de maneira secreta quando a visitavam, mas os laços com os seus pais não foram reatados. Para Yroko, apesar da notável diferença entre o seu padrão de vida e o de seus irmãos, sua maior recompensa foi seguir a vida que escolheu ao constituir a sua família, a família que desejou construir. Nos idos anos 80, ela e seu esposo migraram para o Japão em busca de uma vida melhor. Eles retornaram ao Brasil duas décadas depois, tendo se reestabelecido por aqui.

Suzana, por sua vez, era uma jovem issei que se apaixonou por um brasileiro aos 18 anos e, diante da recusa de sua família, ela se casou com ele ao preço do rompimento familiar. $\mathrm{O}$ casamento foi celebrado sem a presença da família dela. Os primeiros meses de seu casamento foram vividos com alegria. Com a chegada do seu primeiro e único filho, contudo, o seu então

\footnotetext{
${ }^{16}$ A dificuldade em obter dados estatísticos se deu pelo fato de que, para muitas famílias, esse tema é ainda um tabu. As poucas histórias que pude conhecer sobre os casamentos de issei com brasileiros me chegaram na forma de narrativas, memórias das pessoas mais velhas. Há silêncio sobre esse tema na primeira geração por se tratar de um drama social para a "colônia" e ainda gerar sofrimentos nas famílias. A minha família paterna viveu isso. O pai de minha avó paterna não autorizava o casamento com brasileiros. Meu bisavô Kingoro (militar aposentado) embarcou para o Brasil em 1932 junto de sua esposa Oshin e seus três filhos ainda crianças, que viriam a ser minha tia avó Teru, minha avó Setsu e meu tio avô Taro. Minha bisavó faleceu com câncer nos anos 50. Meu bisavô dispensou todas as economias da família em busca de sua cura. Somente minha avó realizou o miai, aos 22 anos, se divorciando seis anos depois. Minha tia avó Teru faleceu solteira perto de seus quarenta anos. E meu tio avô Tarô assumiu o tronco familiar. Já com seus noventa anos, ele relatou que sempre quis se casar com brasileira, mas, para não desrespeitar seu pai, ele se manteve solteiro e a cumprir sua filiação. Com o falecimento de meu bisavô, Tarô se casou aos 64 anos com Teresa, brasileira, 42 anos, e tiveram um filho. Meu tio avô esperou a morte de seu pai para poder se casar com Teresa.

${ }^{17}$ Todos os nomes dos interlocutores foram alterados para preservar suas identidades.

${ }^{18}$ Iolanda era issei, nasceu em 1940. Quando relatou à minha mãe a sua história de vida, ela já tinha 40 anos. Eu a conheci quando era criança. Ela tinha amizade com minha mãe, pois uma vez relatou que seu pai queria fazer o miai com minha avó Setsu, mas ela teria recusado. O miai não era propriamente uma imposição das famílias, tal como aos olhos do amor romântico ocidental moderno. Ele era um dever, mas, para sua concretização, cabia a aceitação por parte dos noivos, também. Se uma jovem recusasse o miai, logo as famílias passavam a acionar uma rede de relações para buscar novos pretendentes. Para mais, ver Sakurai (1993) e Vieira (1973).

${ }^{19}$ Yroko, issei, 70 anos, do lar e ex dekasegui.

${ }^{20}$ Suzana nasceu no Japão em 1936, e sua família migrou para o Brasil no mesmo ano. Casou-se aos 18 anos e aos 20 foi abandonada pelo esposo. Por toda a vida adulta foi auxiliar de limpeza, aposentando-se nessa profissão. Faleceu no ano de 2010, aos 74 anos.
} 
esposo a abandonou com o menino na calada da noite e não deu mais notícias. Ela viveu uma vida muito simples e difícil para criá-lo sem poder contar com o apoio afetivo e financeiro de sua família e tampouco da família do pai de seu filho. Suzana não se casou novamente. Ela faleceu em 2010 e, apesar de eu me recordar de sua vida muito modesta, ela sempre se manteve gentil, com um sorriso leve no rosto.

Apesar de o casamento com "brasileiros" implicar rompimentos familiares, deserdação $e$ históricos de suicídio sobretudo entre os homens, ao comparar as histórias de homens e mulheres issei e nissei que se casaram com não nipônicos, pode-se notar diferentes relações de forças em suas narrativas. Se discursivamente sobre os filhos homens pairava o peso da ruptura do tronco familiar, as mulheres sofriam as consequências desse rompimento de maneira mais intensa, pois, além do estigma da quebra familiar, elas vivenciariam maiores dificuldades econômicas. E para além da mulher nikkey, a mulher "brasileira" casada com "japonês" também seria concebida como o agente maior do rompimento pelo desvio da ordem familiar.

Em Marília, conheci Sonia ${ }^{21}$, uma "brasileira" que se casou aos 24 anos com um nissei. Ela relatou que seu sogro não aceitou o casamento deles por anos: seu então esposo conseguia visitar a mãe com pouca frequência e de forma muito rápida, mas seu pai não dirigia a palavra a ele. Sonia não podia descer do carro e adentrar a casa, sua sogra tentava vê-la rapidamente e de forma escondida: "minha sogra, coitada, gostava de mim e me aceitava, mas meu sogro não, ele não nos aceitava". As diferentes hierarquias e relações de forças sobre os gêneros abriam uma pequena brecha de comunicação mais para os homens do que para as mulheres. Aqui, as histórias de Yroko, Suzana e Sonia se encontram no isolamento familiar imposto pela lógica do ie. No caso de Sonia e sua sogra, o peso do verbo do chefe cerceava com maior força a troca de palavras e o convívio físico entre as mulheres. Mas, na esteira de Ortner (2007) e parafraseando Leonard Cohen em Anthem, é também pela ruptura que a luz entra. Sonia relatou que foi somente alguns anos após o nascimento de suas duas filhas que seu sogro "se apegou a elas" $e$, aos poucos, aceitou primeiramente o filho e depois a nora $e$ os reintegrou ao convívio familiar. A vinda das netas reintegrou o filho e sua família ao seio do ie, e aqui as histórias de Yroko, Suzana e Sonia se desencontram, pois Yroko e Suzana não tiveram o desfecho da aceitação e reintegração em sua família de origem.

\section{Relações de forças e afetividades}

A vinda das filhas de Sonia gerou uma agência inesperada na vida e no tempo. Nesse movimento, a figura do "mestiço", a materialidade da derivação da ruptura no parentesco, agenciou pelo afeto a reintegração de vínculos entre os entes. $\mathrm{E}$, nesse caso, as netas mulheres foram a força reatadora dos laços um dia rompidos. Já as histórias de vida de mulheres sansei casadas com "brasileiros" que conheci, não deixaram de contar com a recusa da família em aceitar o cônjuge "brasileiro", mas essa geração conseguiu negociar suas escolhas com maior força nas relações de poder da família e comunidade. Entretanto, ao comparar mulheres e homens das gerações issei, nissei e sansei casados com "brasileiros", vê-se que os homens teriam maior capital político para inserir suas esposas "brasileiras" nos círculos sociais nikkey do que as mulheres para inserir seus esposos "brasileiros". Tal dimensão é claramente exposta por Sandra, na ocasião da pesquisa, ao frequentar o trabalho voluntário e os cultos dominicais na $\mathrm{IMeL}^{22}$. Sandra é nissei não

\footnotetext{
${ }^{21}$ Sonia, 50 anos na data da entrevista (2015), foi casada com um nissei. Ela relatou ter se divorciado dele após 10 anos de casamento, pois ela era a única a trabalhar, sustentar a casa e cuidar das duas filhas. Seu ex-esposo era viciado em jogos de azar. Ela relatou que sua irmã e irmão também se casaram com nissei, mas tiveram destinos diferentes. Ambos seguiram casados e teriam sido aceitos pelas famílias de seus cônjuges.

${ }^{22}$ Igreja Metodista Livre - Concílio Nikkei. A IMeL no Brasil possui relação direta e estrita com a imigração japonesa, pois ela foi aportada para o Brasil por missionários japoneses que teriam se convertido ao metodismo livre no início do século XX nos Estados Unidos da América. Quando os missionários japoneses observaram a grande onda migratória de conterrâneos para o Brasil, eles migram para cá para fundar a IMeL - Concílio Nikkei e converter os imigrantes. Por somente se comunicar em língua japonesa e inglesa, a fundação da ImeL no Brasil esteve ligada intimamente com a história da imigração e presença nipônica no Brasil. Para mais, ver Hatugai (2018) e Takara (2003). Sobre a Igreja Metodista Livre - Concílio Nikkei no Brasil, consultar Takara (2003).
} 
miscigenada, tem 40 anos e hoje é casada com "brasileiro". Como eu sempre observava, Sandra frequentava a $\mathrm{IMeL}$ somente com sua filha. Eu perguntei a ela se o seu esposo não frequentava o local por ser de outra religião. E ela me explicou:

Não, ele não vem aqui, ele vai na Assembleia, ele já tentou frequentar aqui, mas não vem mais (aqui), você sabe porquê, né?

\section{Eu respondi que não sabia. Então, Sandra confidenciou:}

Você sabe como é "japonês", ele não vem aqui porque ele é "brasileiro", ele não se sente bem aqui. Essa aqui é a nossa igreja, é igreja de "japonês". Aqui é fechado.

A experiência de Sandra intercruza várias dimensões, a saber, o parentesco, a afetividade, a religiosidade, preconceitos, identificações e o peso político do coletivo. Primeiramente, vale notar que Sandra, mesmo sendo jovem, relatou refletir ter se casado primeiramente com um nikkey mais em função da noção de parentesco japonês. Ela e seu primeiro esposo se casaram jovens e por livre escolha sem interferência das famílias, mas, com o passar do tempo, sentiam intimamente que seu casamento proporcionava mais alegria às suas famílias do que ao próprio casal. Alguns anos depois, eles se perceberam sacrificando sua felicidade individual ao seguirem casados para não desapontar os pais. E diante das tentativas frustradas de manutenção do casamento, eles se separaram amigavelmente, gerando mais frustração e tristeza para os pais que para eles mesmos. No entanto, quando ela narra seu segundo casamento, o seu semblante muda. Há ênfase na dimensão da escolha individual $e$ o deslocamento da centralidade da família para a sua afetividade $e$ felicidade pessoal. Inicialmente, os pais de Sandra não admitiam o genro "brasileiro", mas, com o tempo, eles aceitaram sua escolha porque, segundo Sandra, sua felicidade era visivel. Ter se casado com quem ela escolheu mais em nome do amor do que em nome da família foi uma chave para a emergência do indivíduo no seio do coletivo, a agência de seu afeto a conduziu para a rota de suas próprias escolhas, tendo, inclusive, provocado alterações na estrutura da ordem de sua família de origem.

Entretanto, uma vez superada a recusa familiar, ela e seu segundo esposo teriam outra barreira com a qual lidar: o universo político nikkey fora da casa, um universo regido pelos homens ocupando os cargos das direções associativas. Em diferentes contextos da pesquisa, era visível a maior presença de famílias "mistas" formadas por homens nikkey. eles possuíam maior poder de troca nas relações de forças em contextos associativos quando em comparação com as mulheres nikkey. Embora homens e mulheres nikkey encontrassem resistências na aceitação social da família e do grupo quando casados com "brasileiros", na esfera pública os homens nikkey conseguiam impor com mais força a presença da esposa "brasileira" por possuírem maior capital político que as mulheres nikkey. E embora houvesse desigualdades nas relações de poder no universo político nikkey impostas às mulheres, nem por isso elas deixariam de se engajar em suas escolhas e afetos.

\section{Agências femininas}

O lugar do afeto é agência nas experiências de vida de mulheres nikkey casadas com "brasileiros". Ainda que elas sofressem maior resistência pública na aceitação e integração de seus companheiros afetivos, o lugar do seu afeto se tornava agência e não deixava de ser força política nesse universo patrilinear. Entre essas interlocutoras, encontrei mulheres e nissei que desafiaram as regras dos jogos sociais, do parentesco e os estereótipos impostos a elas. Aqui, chamo atenção para o movimento do jogo sério na agência de mulheres como Satiko ${ }^{23}$. A seguir, seu relato:

Eu sempre sonhei ter filhos "mestiços" 24 . Eu sabia que só ia ser mãe, se fosse de "mestiço" ou "mestiça". Era coisa de Deus. Sonhava ter filhos "mestiços" com os olhos claros puxadinhos,

\footnotetext{
${ }^{23} \mathrm{Na}$ época da pesquisa, em 2015, Satiko tinha 58 anos. Satiko era nissei não miscigenada e se casou aos 28 de idade com Rubens, tornando-se mãe aos 30 anos. No ano da entrevista, Rubens tinha 60 anos. Satiko e Rubens já eram aposentados.

24 "Mestiço/mestiça" aqui são categorias nativas exclusivas para se referir a nipodescendentes de japoneses miscigenados. Quando nikkey falam "mestiço/mestiça", eles não estão a falar sobre a concepção mestiço do pensamento social brasileiro
} 
para mim "mestiço" era a coisa mais linda. O meu pai era issei e então queria que eu e minhas irmãs nos casássemos só com "japonês". Mas eu falava que não ia casar forçada, que eu ia ficar solteira! Então, como eu e minhas irmãs tínhamos o nosso negócio, vendíamos comida pronta, hoje fala rotisserie, a gente era independente, eu falava que ia morrer solteira, mas não ia casar forçada por miai. Daí, eu estou lá trabalhando, o Rubens começou a trabalhar na cidade [Oriente], ele ia comprar almoço todos os dias e sempre puxava conversa, mas eu nem dava bola. Imagina, né. Daí, o tempo foi passando e eu comecei a olhar para ele de jeito diferente. $\mathrm{E}$ nós fizemos amizade aos poucos, depois de muita conversa começamos a namorar. Daí, eu falei para a minha família que queria casar com ele e se não fosse [com ele] eu ia ficar solteira. Mas como eu já era independente, meu pai também não podia me obrigar a fazer miai. E nos casamos, nós temos um casal de filhos, a menina mora e trabalha em São Paulo. E os meus filhos nasceram do jeito que eu sempre sonhei: "mestiços" dos olhos verdes. Eles são lindos. Veja só o meu filho, que homão alto e forte com os olhos verdes puxadinhos. E a minha nora, que ele conheceu quando trabalhava no Japão, ela é linda, "mestiça" também e tem os olhos claros. E Deus realizou o meu sonho porque eu pedia para ele [Deus] e ele me atendeu.

Importante notar a fala de Satiko, pois, sendo ela nissei e mulher, a realização do seu desejo de ter filhos "mestiços" foi possibilitada pela decisão de seguir seu sonho, por sua independência financeira e pelo acaso do jogo do amor no encontro com Rubens. Afeto, jogo e independência financeira fizeram total diferença para a concretização de seu casamento em sua família e na sua geração. A ênfase do "mestiço" como mais belo dá mostras das concepções de beleza nikkey, distantes de um olhar orientalista (Said, 1990), pois não se trataria de conceber como belo uma representação "ocidental" euro-americana e/ou tampouco uma homogeneidade "ocidental" ou "asiática". O mais belo seria aquele que promoveria uma beleza diferenciante nikkey, uma multiplicação de novas diferenças, mas que, ainda sim, carregaria em sua corporalidade traços "japoneses" em um meio desejante de continuidades interruptas (Hatugai, 2018). Se considerarmos a experiência de vida de Satiko, o lugar das hierarquias em sua geração, vemos que, nas práticas sociais, ela agenciou sua vida pelo afeto, sonhos e autonomia financeira. E mais, ela promoveu instabilidades nos projetos do ordenamento familiar sem que ocorressem rupturas entre ela e sua familia de origem. E os modos como ela conduziu sua vida rompem até a atualidade com o estereótipo da mulher "japonesa" como "submissa e apagada".

Como Satiko, também conheci Letícia (nissei não miscigenada, 45 anos, empresária) e, apesar de não terem a mesma idade, mas serem da mesma geração, com Leticia a agência de seu desejo teve lugar privilegiado em sua vida afetiva. Letícia era viúva de um nissei com quem teve duas filhas, $e$ atualmente estava casada com um sansei não miscigenado. Ela narrou ter predileção por se relacionar com nikkey, mas essa escolha nada tinha a ver com uma imposição de sua família: se tratava de identificações e desejo íntimo. Entretanto, para Letícia, se relacionar com nikkey tinha um filtro: a total condição de eles não serem "japoneses da colônia". Para ela, se encaixava no seu afeto um nikkey que não compartilhasse de uma visão de mundo patriarcal sobre a família e seus papeis sociais. Leticia, sendo nikkey e tendo se casado com nikkey, traz à tona um ponto nevrálgico ao romper com outro estereótipo: o de que nikkey se relaciona com nikkey por imposição grupal e/ou ausência de escolha afetiva. Afinal, por que não se apaixonar por "japoneses"?

Tomando os casos de Satiko e Leticia, podemos inferir que o lugar do matrimônio e as suas escolhas afetivas rompem estereótipos acerca das mulheres "japonesas" como indivíduos sem voz, pois elas conseguiram impor/negociar seus desejos, sonhos, projetos de vida e suas preferências matrimoniais. A agência do desejo íntimo de cada uma delas rompe com visões monolíticas intercruzadas sobre gênero e raça impostas às mulheres nikkey. Pois, ao protagonizarem suas vidas com escolhas e afetos, elas desafiaram a história da imigração, o parentesco e preconceitos, fazendo emergir individualização no coletivo. E sobretudo Satiko agenciou novos arranjos familiares e produção de pessoas onde antes governava uma perpetuidade patrilinear.

sobre o desejo de caldeamento, e sim a comunicar uma derivação no parentesco que marcará passagens e emanações japonesas se tratando, inclusive, da produção de uma nova corporalidade concebida como mais bela. 


\section{Estereotipias, sexualizações e jogos com os corpos}

Piscitelli (2008) e Corrêa (1996) discutiram vigorosamente as imagens estereotipadas das mulheres brasileiras: o estereótipo exotizado, sexualizado, racializado e tropicalizado da brasileira como afrodescendente miscigenada, a "mulata", sensual, disponível para o labor braçal, ávida por sexo, destinada à maternidade e à prostituição. Acerca dos apelos para com as mulheres latinas trazidos por Piscitelli, eles não abarcariam todos os países e grupos étnicos da América Latina: tais estereotipias pairam com força sobre as mulheres afrodescendentes miscigenadas no Brasil, na Colômbia e no Caribe. Na visão brasileira, as mulheres indígenas da América Latina não estariam inclusas nessa dita concepção de belo e sexual desejante, sendo reservado a elas o distanciamento imagético de um "ideário" de beleza latina ${ }^{25}$. E aqui, a isso, eu somaria a não inclusão das mulheres brasileiras nipodescendentes dentro dessa estereotipia, pois no Brasil a mulher nipodescendente não está inclusa no imaginário de nação, mas elas enfrentariam formas outras de sexualização.

Mesmo estando fora do imaginário de mulher brasileira, as mulheres nikkey sofrem igualmente sexualizações raciais múltiplas, pois se de um lado ainda paira o estereótipo errôneo $e$ hipersexualizado do papel da mulher gueixa como serva submissa ávida por sexo sobre as nikkey, há também outra face perversa do estereótipo da mulher "japonesa" como uma mulher "apagada" e hiposexualizada, pois seu corpo físico não seria atraente o bastante por ser não curvilínea e não se encaixar na estereotipia das mulheres brasileiras.

Certa ocasião, ao conversar com um casal de "mestiços", ouvi do filho de Satiko: "Homem 'japonês' prefere 'brasileira' porque a 'japonesa' nada". Como eu não havia compreendido, eu pedi para ele me explicar mais. Ao que ele respondeu se tratar de uma piada: "Mulher 'japonesa' nada: nada de frente, nada de costas, nada de peito, nada de bunda: reta!". A seguir sua esposa me chamou à observação: "Você pode reparar que nas mulheres 'japonesas' aqui, elas não são bonitas, elas não têm o corpo bonito, elas são retas. Mas elas estão sempre muito bem arrumadas". Eu disse que via como bonitas tanto as "japonesas" do Brasil como as japonesas do Japão. E eles responderam com ênfase:

Ah não, elas não são bonitas. Elas são bem produzidas! Elas têm recursos, dinheiro para se cuidar: elas se vestem bem, gostam de cuidar dos cabelos, têm sempre um corte bonito, elas cuidam da pele e gostam e sabe usar a maquiagem. Pode notar, aqui, as "mestiças" são as mais bonitas.

Diante do etnocentrismo "mestiço", fiquei a refletir como eles posicionariam as suas mães nessa lógica de beleza, uma vez que elas eram nipodescendentes não miscigenadas. As mães seriam desprovidas de sensualidade e beleza físicas, restando a elas tão somente a beleza do corpo moral? É perverso o entranhamento dos preconceitos e da sexualização dos corpos femininos na sociedade brasileira e o modo como essa estrutura atravessava os nipodescendentes ao narrarem sobre outros nipodescendentes. Nesse caso, uma vez que o preconceito e imaginário de exotismo e erotização da gueixa deixava de estar presente, entrava em cena outro modus de sexualização dos corpos femininos nipônicos: a intersecção de uma concepção de fealdade atribuída às mulheres com a hiposexualização dos seus corpos. Intercruzamentos que reduziam a figura da mulher, no apagamento do seu corpo, a uma corporalidade desprovida de formas, de apelos, de marcas e qualidades estéticas e que necessitava de uma agência estética externa para lhes atribuir formas, marcas, beleza.

Reiteradamente, acerca dos corpos e da beleza nipodescendentes, há diferenças entre os relatos de "mestiços", "japoneses" e "brasileiros". Na sociedade brasileira, os corpos dos "japoneses" são vistos majoritariamente como uma corporalidade política investida de imaginário positivado, mas desprovido de sex appeal. Os homens são estigmatizados como impotentes sexuais

\footnotetext{
${ }^{25} \mathrm{Na}$ esteira de Lasmar (1999), embora as mulheres ameríndias de diferentes etnias não estejam inseridas nesse imaginário de mulher latina, não deixa de ocorrer com elas processos de exotização de sua beleza como um estado natural que gravita entre "o bom selvagem" e o "bárbaro", bem como a hipersexualidade e objetificação de seus corpos como disponíveis para o sexo e suscetível à violência desde o período colonial em nossa sociedade.
} 
por imaginariamente possuírem o "pênis pequeno" ${ }^{26}$, e as mulheres são estigmatizadas por serem "retas" e não sensuais, como se compreende ser o corpo da mulher na sociedade brasileira.

Contudo, na visão dos "japoneses", os corpos nikkey miscigenados e não miscigenados são todos investidos de beleza e, notadamente, a corporalidade "mestiça" seria considerada a mais bela entre eles, sem que isso anulasse a beleza da corporalidade "japonesa". Mas para os "brasileiros" $e$ os próprios "mestiços", o corpo "mestiço" seria o mais investido de beleza e sex appeal entre os nipodescendentes principalmente. As mulheres simbolizariam beleza e exotismo ao conjugar ditas corporalidades "oriental" e "ocidental", sendo tidas como mais curvilíneas que as "japonesas" $e$ menos curvilíneas que as "brasileiras". Essas mulheres e seus corpos seriam atravessados por moralidades e exotizações sexuais múltiplas, com um tipo de sex appeal que impõe a elas um controle sobre seus corpos ao terem que conjugar sensualidade e moralidades entendidas como "discrição", expressa pela "delicadeza" dos gestos corporais atrelados ao imaginário sobre as mulheres nipônicas.

Entretanto, há que se ater ao dado que indica que, entre os nikkey, isso nada tem a ver com a ocidentalização do corpo nipodescendente, mas sim com a emergência de um belo nikkey diferente. A suavização dos traços nikkey seria a marca do belo "mestiço" com os olhos mais redondos e "puxadinhos no canto", o nariz mais fino e, enfaticamente, a presença da pálpebra marcante nos olhos $^{27}$. Esses seriam os símbolos que fazem do "mestiço" o mais belo entre os "japoneses", mas ele só seria o mais belo se a sua corporalidade correspondesse com a do grupo. Dito de outra forma, ele seria o mais belo desde que as derivações constantes no parentesco não apagassem os traços corporais nipônicos. Pois, ao se afastar demasiadamente da centralidade do parentesco, esse "mestiço" já não seria mais reconhecido como nipodescendente, não seria mais símbolo de belo $e$ habitaria outro espectro das sociabilidades, tornando-se um "brasileiro".

Centrando-se na corporalidade, tais tensões intersectam os corpos nipodescendentes, diferenciando-os entre corpo político-moral e corpo da beleza. Sobre os corpos nipodescendentes no Brasil, os "japoneses" seriam desprovidos do imaginário de beleza brasileira, mas positivados como corpos-modelo político, ao passo que a corporalidade "mestiça" se reduziria à esfera do físico corporal e belo desejante, mas não seria vista como um modelo moral. E as mulheres "mestiças" seriam as mais impactadas com tal estereotipia ao ter que conjugar e conviver com a exotização de sua beleza e um sex appeal atribuído a elas, se equilibrando entre sensualidade e controle dos gestos e contornos corporais.

Mas não nos enganemos ao pensar que "japoneses" e "mestiços" se submetam aos papeis que a sociedade majoritária busca impor a eles. Eles se engajam e agenciam bem esse jogo, construindo canais de exaltação do belo nipônico e conjugando com consciência as imagens míticas de moralidade sobre eles, usando-as também como negociações na vida cotidiana. Sobretudo os "mestiços" relatam como o mito dos "japoneses" serem concebidos como modelo de retidão os auxiliaria nas relações sociais: ao jogar com a parte de sua ascendência nipônica, obteriam mais confiança alheia na vida social (Hatugai, 2011, 2018).

\section{Dos mais belos}

As descrições de beleza nikkey possuíam mais força quando se tratava da beleza $e$ corporalidadade das mulheres nipodescendentes não miscigenadas e miscigenadas. A saber, no ano de 2015, acompanhei toda a movimentação do Japan Fest em Marília ${ }^{28}$ e do concurso Miss Nikkey. Interroguei meus interlocutores sobre a eleição do Miss Nikkey e sobre os símbolos e significados desse concurso. A ideia de criar o Miss Nikkey dentro do Japan Fest se deu por parte da geração nissei mais jovem dentro da "colônia", pois, segundo Seiji, o propósito absoluto dizia respeito a autoestima do nikkey. Segundo ele, por toda sua infância e juventude ele se cansou de ouvir que os "japoneses eram feios e ingênuos" e dizia que o seu intuito era promover a consciência da beleza

\footnotetext{
${ }^{26}$ Ver Ribeira (2011).

${ }^{27}$ Sobre a ênfase na "pálpebra" ver Schpun (2007) e Watarai neste dossiê.

${ }^{28}$ A maior festa da cultura japonesa do interior de São Paulo.
} 
dos nikkey, sua autoestima e representatividade social. Em entrevista com Tiemi ${ }^{29}$, eu adentrei no assunto Miss Nikkey, visto que Tiemi era uma das pessoas encarregadas das inscrições do concurso. Ela não participava das avaliações posteriores às inscrições, mas cabia a ela a conferência dos documentos necessários que certificassem formalmente a descendência japonesa das candidatas por meio de certidões de nascimento, casamentos dos pais, avós ou bisavós, ou ainda, por meio do Koseki Tohon, o Registro de Família japonês ${ }^{30}$.

Como Tiemi acompanhava o concurso há anos, eu interroguei se ela poderia avaliar se havia mais misses "japonesas" ou "mestiças". E ela me disse que, há poucos anos, eles perceberam que teriam que compor a banca de jurados por metade nipodescendentes e metade "brasileiros". Toda a organização havia notado que somente as "mestiças" ganhavam o concurso, e observou-se que havia sempre mais jurados "brasileiros" que "japoneses" na banca. A partir disso, eles decidiram equiparar a banca para que se tivesse a apreciação e um resultado justo acerca da beleza no Miss Nikkey.

Antes, só ganhava "mestiça". Isso não significa que "mestiça" não pode ganhar, mas também não significa que "japonesa" é feia. Antes a banca do jurado tinha mais "brasileiros". Então, nós pensamos, todo mundo aqui pensou: e se fizer a banca de metade "brasileiro" e metade "japonês"? Ficou mais igual, por qué? Para o "brasileiro", a "mestiça" vai ser sempre a mais bonita, eles não conseguem entender a beleza da "japonesa", que é mais delicada: o corpo, o seio e o bumbum são menores. A "mestiça" não vai ter curvas como a "brasileira", mas ela tem mais curvas que a "japonesa". O "brasileiro" vai ver a beleza do jeito que ele entende que é [a beleza]. Com a banca de metade "japonesa" e metade "brasileira", a gente passou a ter miss "japonesa" e miss "mestiça", e não só "mestiça". O "japonês" entende a beleza da "japonesa" e também gosta desse tipo de beleza. Para você ver, a miss desse ano [2015] é "japonesa pura".

Tiemi traz à tona a percepção de diferentes concepções de beleza entre "japoneses" $e$ "brasileiros" ao tecer análises sobre uma concepção etnocêntrica e sexualizada que há na sociedade brasileira acerca da beleza dos corpos femininos. E mais, Tiemi observou essa concepção de beleza por meio da erotização desses corpos no Brasil com a predileção, erotização e sexualização do corpo feminino em nádegas, seios e quadril avantajados e torneados. Ela observou que entre os "brasileiros" haveria a preferencia pelo corpo feminino curvilíneo e abundante de formas, e, devido a isso, dificilmente o "brasileiro" notaria e conceberia como belo e atraente o corpo mais "delicado" das "japonesas". E justamente em face a essa predileção e erotização, Tiemi $e$ a organização do evento, inferiram que a beleza da "japonesa pura" (não miscigenada) seria mais valorizada e eleita se houvesse mais nipodescendentes na banca de jurados. Essa medida equilibraria a disputa pelo título de beleza entre as nipodescendentes "puras" e "mestiças". Segundo ela, a própria vencedora do Miss Nikkey 2015 seria a prova disso. A ênfase acerca da beleza da Miss Nikkey 2015 ser "japonesa pura" era uma ênfase local que eu já havia escutado de várias pessoas de dentro e de fora da "colônia".

No trabalho voluntário na "colônia", eu conheci e entrevistei a estudante vencedora do concurso. Ela era bela, e seu biotipo, de fato, se assemelhava ao de uma nipodescendente não miscigenada. Além de sua família frequentar a "colônia", ela era também atleta de baseball lá. Perguntei sobre a sua candidatura e como ela se sentia em relação ao título. Ela disse que não

\footnotetext{
${ }^{29}$ Sansei não miscigenada, 35 anos, administradora, casada com "brasileiro".

${ }^{30}$ De acordo com Sasaki (2009) e Silva (2012), em 1871 o governo japonês criou a Lei de Registro Civil, um banco de dados nacional de todas as famílias japonesas contendo nome e sobrenome. Para além de reunir os dados de todas as familias, tal mapeamento visou reunir os japoneses e tecer a concepção do "súdito" japonês comum sob o projeto e discurso de unificação do povo e enriquecimento da nação estabelecendo-se daí fortes relações entre o governo e povo. Nesse sentido, como apontado por Silva (2012), a instituição do ie passa a ser reflexo na política de intermediação entre o Estado e as famílias e as relações de hierarquia do ie passam a coincidir com as relações hierarquizantes do governo para com os seus súditos. Nesse momento histórico, se instituiu juridicamente a definição de quem é japonês e quem é descendente (pelo princípio da patrilinearidade) e se firmou o direito de cidadania japonesa por meio do princípio Jus Sanguinis. O sangue e o registro nacional Koseki Tohon passaram a assumir valor e atribuições jurídicas acerca dos direitos e deveres dos cidadãos japoneses e a definir quem é japonês.
} 
pensava em concorrer, mas sua família e amigos sempre a incentivaram, ela via a eleição como acaso. Perguntei como ela se sentia com o título $e$ se sua vida e percepções de beleza $e$ nipodescendência haviam mudado com o concurso, ao que ela respondeu:

Não mudou nada na minha rotina, eu não fico pensando em beleza, eu sou focada nos estudos $e$ no futuro com o vestibular. Para mim, o mais importante sobre o concurso é que eu vou representar a "colônia" por um ano. Então, eu vejo isso com muita responsabilidade, porque é a representação dos nossos valores.

Ela era jovem, bela, inteligente e articulada e em seu discurso. Mais que a beleza, valia a concepção de postura da "colônia" atravessada pelo senso de coletividade nikkey. Me chamava atenção o fato de as pessoas enfatizarem a sua beleza sempre associando-a à sua educação familiar de orientação japonesa e ser "japonesa pura": ela catalisava as identificações e representava os nipodescendentes acerca da valorização e reconhecimento da beleza nikkey por meio da beleza física e corpo moral de orientação japonesa imigrante.

Certa semana, eu fui convidada por um grupo de mulheres nikkey para um jantar que elas realizavam mensalmente em um restaurante da cidade. A certa altura, em conversa com uma nissei não miscigenada sentada ao meu lado, eu descobri que ela era mãe da Miss Nikkey Marília 2015. Eu a parabenizei pela sua filha e comentei sobre o orgulho dos interlocutores por ela ser "japonesa". Ela agradeceu, mas advertiu que sua filha era "mestiça" e emendou: "Ah sim, as pessoas se confundem, ela é 'mestiça'. O meu esposo é sansei 'mestiço'. Eu sou nissei. A minha filha é "mestiça'".

Podemos inferir que, para a mãe, o fato de ela ser "japonesa" e seu esposo "mestiç,", logo os filhos deles seriam "mestiços". Ou seja, por mais que as marcas corporais simbólicas de seus filhos em nada se assemelhassem ao que se concebe como um biotipo "mestic,o", pelas regras do parentesco e em reflexão com uma dita japonidade difundida entre a presença japonesa no Brasil, por mais que a jovem não aparentasse, ela era "mestiça" (Hatugai, 2018). Dessa forma, da união entre "mestiços" e "japoneses" há a produção de novas diferenças e novas descendências e uma maior complexidade no entrelaçamento entre corporalidade, beleza, parentesco e estereótipos.

A estereotipia acerca do corpo "mestiço" como uma fronteira que marca derivações no parentesco possuía o poder de confrontar diretamente as regras já estabelecidas pelo sistema. Visualizamos nessa prática social um jogo complexo ao interrelacionar parentesco, pertencimentos, gênero, beleza, sex appeal e corporalidades na imagem da jovem miss com traç,os, gestos e saberes $e$ a sua posição central no parentesco mesmo se tratando de uma nipodescendente "mestiça". Tais intersecções, expostas na corporalidade da jovem miss, nos dão mostras da força das estereotipias e de como a imagem que se faz sobre o corpo e a presença dos elementos simbólicos que compõem uma dita corporalidade "japonesa" não são registros fixos e impermeáveis nos casos reais.

A jovem miss estava distante do preconceito e estereótipo dos "mestiços" como afastados da cultura e parentesco "japonês". Uma corporalidade inesperada que confrontava as regras do sistema e os imaginários sociais.

Assim sendo, o "mestiço", e mais precisamente, as mulheres "mestiças", ao estabelecer uma fronteira permeável no parentesco por meio de ditas derivações corporais, sanguíneas, de nomes e cultura, dão mostras de como os sujeitos são capazes de confrontar, também silenciosamente, o sistema e expor em sua própria corporalidade com maior nitidez os estereótipos sociais e do parentesco acerca das mulheres "japonesas" e "mestiças". E por meio de uma brecha, as "mestiças" fabricariam agências, que são símbolo significativo de corporalidades e novos arranjos no parentesco. Pois, historicamente, aquele que veio para instaurar a derivação no parentesco, agora o conduzia inesperadamente para a sua centralidade.

\section{Considerações finais}

Desafiando estereotipias, as mulheres nipodescendentes "japonesas" e "mestiças" possuem $e$ fabricam agências em contextos associativos e para com a sociedade majoritária. Apesar de pairar sobre a mulher "japonesa" a estereotipia de "submissa", conhecemos histórias de vida em que elas são protagonistas de suas estéticas e vidas afetivas, fazendo de seu afeto capital político em 
territórios marcadamente patrilineares. Acerca da "mestiça", vimos como elas são símbolos de beleza, mas não se reduzem ao sex appeal atribuído a elas, bem como elas agenciam plasticidades no parentesco "japonês" do Brasil por meio de suas corporalidades. Apesar da pouca abordagem sobre o papel central das mulheres nipônicas na literatura mais tradicional sobre imigração japonesa e da lacuna sobre a figura e existência dos "mestiços", vimos aqui novas possibilidades para compreender papeis e agências femininas nesse contexto migratório e os novos movimentos "mestiços", caminhando para a centralidade do parentesco. Há aí lacunas entre as regras inscritas e ratificadas como específicas do parentesco japonês imigrante, encaminhando-o para a derivação "mestiça", e um retorno inesperado ao centro do parentesco a partir da união entre "mestiços" e "japoneses", além de novas passagens "mestiças" entre as regras do parentesco e o vivido, simbolizados na corporalidade de uma jovem miss "mestiça".

\section{Referências bibliográficas}

BRAH, Avtar. Diferença, diversidade, diferenciação. cadernos pagu (26), Campinas, SP, Núcleo de Estudos de Gênero-Pagu/Unicamp, 2006, pp.329-365 [https://doi.org/10.1590/S0104-83332006000100014 acesso em: 10 maio 2019].

CARDOSO, Ruth C. L. Estrutura familiar e mobilidade social: estudo dos japoneses no Estado de São Paulo. In: NINOMIYA, M. (org.). Pesquisa da população de descendentes de japoneses no Brasil 1987 - 1988. São Paulo, Kaleidos-Primus. Consultoria e Comunicação Integrada S/C Ltda. 1998; Centro de Estudos Nipo-Brasileiros. São Paulo, 1990.

DEZEM, Rogério. Matizes do "amarelo": a gênese dos discursos sobre orientais no Brasil (1878- 1908). São Paulo, Associação Editorial Humanitas, 2005.

ELIAS, Norbert; SCOTSON, John L. Os estabelecidos e os outsiders. Sociologia das relações de poder a partir de uma pequena comunidade. Rio de Janeiro, Zahar, 2000.

GUIMARÃES, A. S. A. Racismo e anti-racismo no Brasil. São Paulo, 34, 1999.

HANDA, Tomo. Senso estético na vida dos Imigrantes Japoneses. In: SAITO, H.; MAEYAMA, T. Estudos Brasileiros (org.). Assimilação e integração dos japoneses no Brasil. Petrópolis, Vozes; São Paulo, Edusp, 1973, pp.71-163.

HATUGAI, Érica R. Um corpo como fronteira. Parentesco e identificações entre descendentes nipônicos e "mestiços". Tese (Doutorado em Antropologia Social), Universidade Federal de São Carlos, São Carlos, 2018.

Feito por mulheres: as japonesidades pela ótica e mãos femininas. In: MACHADO, I. J. R. (org). Deslocamento e parentesco. São Carlos, Ed. EdUFSCar, 2013, pp.127-144.

A medida das coisas: japonesidades e parentesco entre associados da Nipo em Araraquara. Dissertação (Mestrado em Antropologia Social), Universidade Federal de São Carlos, São Carlos, 2011.

KEBBE, Victor H.; MACHADO, Igor. J. R. Mito do sucesso da imigração japonesa, dekasseguis e o sonho da comunidade nikkei. In: ZANINI, C. M. et alii (org.). Migraçóes internacionais. valores, capitais e práticas em deslocamentos. Santa Maria, UFMS, 2013, pp.157-190.

KUBOTA, N. F. L. Heterogeneidade nikkei em Campo Grande: relações genealógicas entre okinawanos e não okinawanos. In: MACHADO, I. J. R. (org.). Deslocamento e parentesco. São Carlos, EDUFSCar, 2013, pp.25-49.

LASMAR, Cristiane. Mulheres indígenas: representações. Revista Estudos Femininos, v. 7, n. 1 e 2, 1999, pp.143-156. Dossiê Mulheres Indígenas.

LESSER, Jeffrey. A negociação da identidade nacional. Imigrantes, minorias e a luta pela etnicidade no Brasil. São Paulo, UNESP, 2001.

MACHADO, Igor J. R. (org.). Deslocamentos e parentesco. São Carlos, EdUFSCar, 2015.

(org). Japonesidades multiplicadas. Novos estudos sobre a presença japonesa no Brasil. São Carlos, EdUFSCar, 2011. 
NOGUEIRA Oracy. Preconceito de marca. As relações raciais em Itapetininga. São Paulo, Edusp, 1998. Apresentação e edição de Maria Laura Viveiros de Castro Cavalcanti.

ORTNER, Sherry B. Poder e projetos: Reflexões sobre a agência. In.: GROSSI, Miriam Pillar; ECKERT, Cornelia; FRY, Peter Henry (org.). Reunião Brasileira de Antropologia. Anais... Blumenau, Nova Letra, 2007, pp.45-80.

PISCITELLI. Adriana. Interseccionalidades, categorias de articulação e experiências de migrantes brasileiras. Sociedade e Cultura, v. 11, n. 2, 2008, pp.263-274 [https://doi.org/10.5216/sec.v11i2.5247 - acceso em 10 de janeiro de 2020].

RIBEIRA, Fabio R. O estranho enjaulado e o exótico domesticado: reflexões sobre exotismo e abjeção entre nipodescendentes. In: MACHADO, I. J. R. (org.). Japonesidade multiplicadas. Novos estudos sobre a presença japonesa no Brasil. São Carlos, EdUFSCar, 2011, pp.87-114.

SAID, Edward. W. Orientalismo. O oriente como invenção do Ocidente. São Paulo, Companhia das Letras, 1990.

SAKURAI, Célia. Japoneses. São Paulo, Contexto, 2008.

Romanceiro da imigração japonesa. São Paulo, Sumaré, FAPESP, 1993.

SASAKI PINHEIRO, Elisa. M. Ser ou não ser japonês? A construção da identidade os brasileiros descendentes de japoneses no contexto das migrações internacionais do Japão contemporâneo. Tese (Doutorado em Ciências Sociais), Universidade Estadual de Campinas, Campinas, 2009.

SCHPUN, Mônica. R. Imigração japonesa no Brasil: riquezas de uma presença secular. In: INSTITUTO Brasileiro de Geografia e Estatística. Resistência \& Integração: 100 anos de imigração japonesa no Brasil. Rio de Janeiro, 2008, pp.136-149.

.História de uma invenção identitária. A estética nipo-brasileira dos descendentes de imigrantes (temporalidade migratória, etnia e gênero). Coloquios, Puesto em Línea el 14 marzo 2007 [https://journals.openedition.org/nuevomundo/3685\#quotation - acesso em: 10 ago 2013].

SILVA, Victor. H. M. K. Na vida única vez fabricando famílias e relacionalidades entre decasséguis no Japão. Tese (Doutorado em Antropologia Social), Universidade Federal de São Carlos, São Carlos, 2012.

TAKARA, Marcelo. T. O desenvolvimento da Igreja Metodista Livre: Concílio Nikkei no seu processo de aculturação no Brasil: possibilidades contemporâneas de sua missão. Dissertação (Mestrado em Teologia), Faculdade Teológica Batista de São Paulo, São Paulo, 2003.

VIEIRA, Francisca. I. S. O japonês na frente de expansão paulista: o processo de absorção do japonês em Marília. São Paulo, Pioneira/ Universidade de São Paulo, 1973.

WATARAI, Tamaki. Aprendendo a maquiar as hierarquias: corpo "ocidental" e o "oriental" nos cursos de maquiagem da comunidade brasileira no Japão. cadernos pagu (63), Campinas, SP, Núcleo de Estudos de Gênero-Pagu/Unicamp, 2021. DOI http://dx.doi.org/10.1590/18094449202100630003

YAMASHIRO, José. Trajetória de duas vidas. Uma história da imigração e integração. São Paulo, Cultura Editores Associados, 2001.

YANAGISAKO, Sylvia. J. Transforming the past. Tradition and kinship among japanese americans. California, Stanford University Press, 1985. 